\title{
ENCONTRO ENTRE CIÊNCIAS SOCIAIS E CANDOMBLÉ BAIANO: produção científica e engajamento político-cultural: entrevista com Vivaldo da Costa Lima
}

\author{
Edson Farias* \\ Fernando Rodrigues $^{* *}$
}

O decorrer do século XX registra o engajamento dos cientistas sociais com a questão nacional, em países como o Brasil, onde a organização do trabalho dos intelectuais esteve preliminarmente aliada ao modo como o ordenamento estatal se antecipou como núcleo formativo e gestor da consciência e, mais tarde, da cultura brasileira (Carvalho, 2007) Aqui, à maneira da atuação dos literatos românticos e modernistas, mas sobretudo no rastro das repercussões de Casa Grande e Senzala, livro de Gilberto Freyre publicado em 1933, tanto nos encaminhamentos teórico-analíticos das suas pesquisas quanto nas intervenções nos debates públicos, os sociólogos e os antropólogos evidenciaram o compromisso com a construção da Nação. A transição histórica da sociedade agráriorural para a urbano-industrial e, igualmente, a implantação efetiva do regime republicano, alterando os pilares institucionais do país, a um só tempo tanto informou ideários quanto se definiu prioritário objeto de conhecimento. No caudal dessa mudança histórica, os impasses da constituição da sociedade civil e de uma saudável atmosfera democrática fizeram-se oportunos para que à questão do

\footnotetext{
* Professor do Programa de Pós-Graduação em Sociologia da Universidade de Brasília (UnB), pesquisador do grupo Cultura, Memória e Desenvolvimento (Sol-UnB).

** Doutorando do Programa de Pós-Graduação em Sociologia da UnB, pesquisador do grupo Cultura, Memória e Desenvolvimento (SOL/UnB).
}

Transcrição da entrevista realizada por Rosevel Gutemberg.

Artigo apresentado em 9 dez. 2008 e aprovado em 15 jan. 09 
popular coubesse a função de eixo do engajamento entre Ciências Sociais e Nação brasileira. ${ }^{1}$

Tal nacionalização das Ciências Sociais no Brasil adquiriu feições diversas a depender do contexto regional, mas houve um traço em comum e este disse respeito ao interesse na correlação entre grupos subalternos e formação do povo-nação. Assim, a atenção dada por essas disciplinas ao tema da cultura popular esteve em sintonia com o interesse de conhecer e revelar seja as lutas pela sobrevivência, por meio das diversas táticas de inserção e posicionamento na cena sociopolítica brasileira, seja a peculiaridade dos modos de viver, pensar, agir e se expressar das populações pobres.

O recorte étnico no tratamento do tema da cultura popular veio a reboque da percepção de que, no Brasil, o lugar social reservado aos subalternos não se encerrava nos critérios da situação de classe social vinculada à estrutura socioeconômica. ${ }^{2}$ A referência à origem fundada em hipotéticas linhagens raciais e, ainda, o relevo dado a traços fenotípicos, sobretudo a cor da pele, mostraram-se decisivos no delineamento do perfil de muitos entre os grupos da população nacional, definindo inclusive o que seriam os próprios grupos. Quer dizer, a classificação como indígena ou negro pautaria a posição dos membros desses grupos na sociedade nacional. Assim, a herança histórica da escravidão deixou sua marca no que toca à identificação dos grupos definidos e reconhecidos como negros ou mesmo mestiços. Deste modo, os exercícios analíticos e interpretativos focalizaram áreas do país, como a Bahia, onde tal componente sociohistórico estruturou (e ainda tem estruturado) de tantas maneiras as tentativas de inserção e participação de homens e mulheres negras na vida regional e, mediante esta, na construção da Nação.

Portanto, à luz deste quadro, os estudos das humanidades no País incorporaram a discussão sobre as questões étnico-raciais. Em se tratando da Bahia, a partir do pionerismo de Raimundo Nina Rodrigues (2004, 2006) no limiar do século XX, o entrecruzamento 
de estudos antropológicos com os estudos africanistas deu oportunidade a contribuições posteriores, no decorrer dos anos de 1930 e 1940, como as de Arthur Ramos (1979, 2004) e Édison Carneiro (1978, 1981), em diálogo também com os enfoques dos pesquisadores estadunidenses Melville Herskovits (1930), Donald Pierson (1945) e Ruth Landes (2002), em um momento em que as discussões sobre conflitos raciais se tornam um importante foco intelectual-científico e político nos Estados Unidos (cf. Stoking Jr., 2002, Guimarães, 2004, Yelvington, 2007). No rastro deixado por ambos consta tanto a realização do II Congresso Afro-Brasileiro em 1937, em Salvador, quanto a contribuição ao advento da União das Seitas Afro-Brasileiras da Bahia, primeira federação do gênero no país (Oliveira; Lima, 1987).

Mais tarde, a tradição baiana dos estudos africanistas contracenará com as aspirações desenvolvimentistas inscritas no convênio entre a Secretaria da Educação da Bahia e a Universidade de Colúmbia, em 1949, sendo este base para o célebre projeto Unesco no início dos anos cinquenta (Guimarães, 2007, Maio, 1999). São desdobramentos deste último as pesquisas etnográficas e antropológicas tendo por objeto tanto a cultura africana quanto os estudos de comunidades negro-mestiças desenvolvidos ao longo dos anos cinquenta. Situação animada com a edição em Dakar, no Senegal, do livro Notes sur le culte des orisa et vodun à Bahia, la Baie de tous les Saints, au Brésil et à l'ancienne côte des esclaves em Afrique, de Pierre Verger, editado pelo Institut Français d'Afrique Noire (cf. Oliveira, 2004), e, também, com a divulgação em 1958 da obra O Candomblé da Bahia, de um outro francês, sobre os cultos afro-brasileiros - o sociólogo Roger Bastide (2001). Por isto mesmo se constitui em divisor de águas a criação do Centro de Estudos AfroOrientais (CEAO), sob liderança do latinista e filólogo português Agostinho da Silva. Levado ao auto-exílio pela ditadura salazarista, Silva ergueu a bandeira de uma "civilização luso-tupi” que se definiria pela centralidade da cultura em detrimento da centralidade 
gozada pelo dinheiro no capitalismo. Com esse ideário respondeu Agostinho positivamente ao convite do reitor Edgar Santos, ${ }^{3}$ da Universidade da Bahia, em 1959, para implantar o CEAO. Este seria parte das estratégias do governo brasileiro no sistema internacional, em um momento da geopolítica mundial bi-polarizada entre Estados Unidos e União Soviética. Obedeciam-se às orientações diplomáticas em favor do terceiro-mundismo marcante dos governos Juscelino Kubitschek, João Goulart e Jânio Quadros, as quais faziam coro com a proposição da Unesco de intensificar o intercâmbio cultural entre Ocidente e Oriente. E, efetivamente, tais orientações pautaram a política externa do país em relação ao continente africano (Agostinho, 1995). Deste modo foram realizadas as viagens para estudos lingüísticos, históricos e antropológicos de pesquisadores brasileiros à África e à Ásia, incluindo também a montagem de departamentos universitários e centros de pesquisa no Senegal, Bulgária, Ceilão, Índia e Japão.

Em torno da figura de Agostinho da Silva, com seu objetivo de fomentar a possibilidade de elaborar um modelo civilizatório não resignado à mera imitação da Europa ou restrito à cópia da América do Norte, orbitava um quadro de pesquisadores composto por lingüistas, antropólogos, historiadores e mesmo o teatrólogo Nelson de Araújo. Motivado por implantar uma educação capaz de potencializar o artista e cientista existente em qualquer indivíduo, à semelhança do modernismo brasileiro, tal círculo viabilizou estudos que privilegiassem o autóctone, com ênfase posta nas práticas e nos símbolos do que eram reconhecidos como faces da cultura popular. Assim, os traços linguísticos, religiosos e folclórico-culturais da população negro-mestiça de Salvador e adjacências foram conduzidos ao posto de objeto de conhecimento científico.

Baiano de Feira de Santana, o nome do antropólogo e, hoje, professor aposentado do curso de Ciências Sociais da Universidade Federal da Bahia, Vivaldo da Costa Lima, ao lado do historiador 
Waldir Freitas de Oliveira ${ }^{4}$, foi o primeiro a constar no quadro de pesquisadores do CEAO. Com uma obra voltada e consagrada para os estudos do Candomblé, com destaque na pesquisa sobre as "famílias de santo" inter-geracionalmente geradas e habitando nos terreiros desse culto afro-brasileiro, Vivaldo sintetiza em sua trajetória muitos dos aspectos marcantes da relação entre cientistas sociais e cultura popular no Brasil. E isto não apenas no que se refere ao legado das elaborações socioantropológicas, ${ }^{5}$ mas principalmente considerando sua participação nos esforços das lideranças do Candomblé baiano pela legitimação deste credo religioso.

Abaixo, a entrevista com Vivaldo da Costa Lima fez parte de uma pesquisa cujo objetivo era exatamente abordar as convergências entre círculos intelectuais e Estado na montagem do aparato de órgãos de cultura na Bahia. ${ }^{6}$ Concedida durante três dias a Edson Farias e a Fernando Rodrigues, em março de 2004, na casa em que mora no bairro da Pituba em Salvador, na entrevista o antropólogo relata passagens da própria vida e que estão ligadas à história das ciências sociais na Bahia, com evidentes repercussões nos rumos tomados pelo estudo da cultura africana no Brasil. Descreve como trocou a Odontologia pela Antropologia e como se deu a entrada para o CEAO. Instituição pela qual fez a viagem de trabalho até a África, durante três anos no início da década de 1960. Relata os caminhos percorridos na introdução dos estudos étnicos sobre cultura africana na Universidade da Bahia, incrementando o diálogo teórico dos modelos estrutural-funcionalista da escola britânica de Antropologia Social com as margens interpretativistas do culturalismo norte-americano; ao mesmo tempo, exercitou o intercâmbio entre a tradição etnográfica com a proposta da etnohistória. Conta, ainda, da proximidade com as casas do Candomblé e deixa entrever os caminhos percorridos pelas suas lideranças na construção de uma imagem pública de honorabilidade. Ao mesmo tempo, fala do ingresso no poder público e dos dilemas que 
acompanharam a iniciativa, ao compor o grupo de intelectuais e técnicos, que pioneiramente, propuseram e executaram a restauração do Centro Histórico de Salvador.

\section{Entrevista com Vivaldo da Costa Lima}

Edson Farias - Conte-nos sobre sua trajetória: onde o senhor começou a estudar? Como aparece o interesse por Ciências Sociais?

Vivaldo da Costa Lima - Na verdade, eu me formei muito jovem, com 19 anos, numa época em que não havia ainda essa série de cursos aqui na Bahia. A Universidade não tinha ainda decodificado esses cursos, Ciências Sociais, nem nada. O que era... é o seguinte: eu vim d'uma família de nove irmãos, e sou o caçula dos sete homens - depois de mim, uma menina e, antes de mim, outra menina; mas, somos apenas dois homens. Naturalmente que tive um pai de classe média do interior, em Feira de Santana, onde eu nasci. Ele se mudou para Salvador, em 1932, com a família para eu estudar junto com os irmãos, que eram internos em colégios. Eu já não fui interno. Então, eles foram se formando: Direito, Medicina, Engenharia e essas profissões da moda e de prestígio para a classe média. Sobrou para mim o quê? Sobrou para mim a Odontologia. Eu era muito jovem, de uma certa maneira um pouco precoce, e no meu tempo ainda se podia entrar no ginásio antes dos onze anos. Eu entrei no ginásio com dez anos. Então, acabei me formando em Odontologia, e como eu fui estudar Odontologia, eu tive que estudar bem. Naquele tempo, o curso de Odontologia era anexo à Faculdade de Medicina. ${ }^{7}$

Edson Farias - O senhor fez segundo grau onde?

Vivaldo da Costa Lima - Aqui, no Ginásio da Bahia, que era o melhor colégio público naquela época. Hoje é o Colégio da Bahia, mas então chamava-se Ginásio. 
Edson Farias - E era comum a classe média frequentar a escola pública nesse tempo?

Vivaldo da Costa Lima - Mas era, certamente! Era o melhor colégio. Só frequentavam os outros colégios - o (Antônio) Vieira e o Marista -, como meus irmãos freqüentaram, os internos. Quem eram os internos? Gente do interior. Quem frequentava o ginásio público? A gente da burguesia, da alta burguesia, os ricos - que não era o caso da minha família. Mas, naquele tempo era muito comum esse pessoal sair desses ginásios chiques e ir para o Ginásio da Bahia fazer o curso anexo. Todos esses nomes, que estão hoje aí, como professores, fizeram o Ginásio da Bahia, que tinha o melhor curso chamado "complementar". O corpo docente era extraordinário. Nós saíamos do Ginásio diretamente para fazer o vestibular nas faculdades, sem negócio de cursinho, não havia ainda esses cursinhos, essas coisas, essa indústria pedagógica de cursinho, que nivela por baixo o conhecimento das pessoas! Mas isso é outra coisa, eu não estou aqui pra fazer polêmica. Eu me formei em Odontologia em 1945, e como fui um dos dois primeiros alunos da classe, meu prêmio foi ir para São Paulo, porque eu não podia ir para os Estados Unidos naquela época, não tinha condições. E fui para São Paulo fazer um curso de "cirurgia da boca”, cirurgia buco-maxilar, como se chamava antigamente, no Sanatório Esperança, que era o único sanatório da América do Sul onde se fazia especialização odontológica, porque na Bahia não havia sequer ainda um curso de Odontologia separado do curso de Medicina. Mas, então, eu lá em São Paulo fiz esse curso de pós-graduação. Depois, comecei a trabalhar, ainda lá. Morei por quatro anos entre São Paulo e Rio, e vim para a Bahia, mas já não estava satisfeito com a minha atividade profissional. Enfim, não estavam na Odontologia as minhas expectativas existenciais e pessoais. Voltei para cá - para Salvador. Por coincidência, nessa época, comecei a me interessar por estudos de Candomblé, ler, frequentar. Eu já lia muito sobre o assunto e tive a compreensão 
muito grande de meu pai, de minha família, que não se preocupou em financiar, em manter novamente novos custos. Então eu voltei a São Paulo para estudar Ciências Sociais, para fazer curso de graduação, como eu já tinha um título universitário, naquele tempo era possível fazer outro curso universitário sem precisar vestibular. Era tudo muito fácil naquele tempo, porque não havia nenhuma concorrência profissional. Eu fui talvez o último profissional que se aproveitou dessa circunstância de trocar de carreira. O professor Thales de Azevedo, antes de mim, já tinha feito isso. Ele era médico e se tornou professor de Antropologia. Mais tarde, curiosamente, eu o substitui como professor de Antropologia na Faculdade de Filosofia da Universidade da Bahia. ${ }^{8}$

Edson Farias - O senhor foi estudar na USP?

Vivaldo da Costa Lima - Sim, na USP. Aqui, na Bahia, depois, quando eu voltei, fui convidado pelo reitor Edgar Santos para participar do grupo formador do Centro de Estudos Afro-Orientais (CEAO), que foi um centro criado pelo professor Agostinho da Silva. Essa iniciativa do Agostinho da Silva revolucionou realmente a metodologia da pesquisa entre nós, porque nós éramos muito livrescos naquele tempo, e foi Agostinho quem nos deu a oportunidade de viajar, fazer trabalhos de campo. Na época, vivíamos uma situação política de aproximação com a África e com os países africanos, mas se tratava também de um aspecto cultural, não é? Fui eu o primeiro professor a ir para a África por conta da Universidade Federal da Bahia, para fazer pesquisas e estudos na Nigéria, na zona de influência cultural maior aqui na Bahia, da região onde vivem os chamados Nagôs, entre outras etnias. Logo depois, no mesmo ano, foi o professor Pedro Moacir Maia, que hoje também é professor aposentado da Universidade, e é o grande especialista em arte baiana, em arte de azulejaria e em história da arte religiosa, membro da Academia de Letras da Bahia. Depois de nós dois, vieram os outros. A 
professora Ieda de Castro, que hoje é conhecida internacionalmente, por ter livros sobre lingüística africana, ${ }^{9}$ foi a primeira pesquisadora ar sobre linguística africana de um ponto de vista profissional. Seu marido, o professor Guilherme de Souza Castro - já falecido -, todos eles foram para a África ensinar profissionalmente. Embora eu não tivesse nenhuma formação pedagógica nem didática para ensinar português, eu dei um curso inicial de português para alunos da Nigéria que queriam vir para o Brasil, com bolsas de estudos, estudar aqui. Lá, na África, os estudantes ficavam “caçando", a expressão é essa, caçando bolsas de estudos fora do país. Naturalmente, a preferência era para os países ricos. Esses países tinham interesse em ter esses alunos. A Inglaterra, por exemplo, era ligada à Nigéria pela tradição colonial. Os Estados Unidos sempre tiveram interesses políticos em ter africanos formados em suas universidades, por uma questão de dominação política que continua até hoje. A colonização francesa na África foi muito grande, também. Porém, o Brasil era completamente ignorado, porque não tinha tradição de bolsistas. Os primeiros bolsistas vieram para aqui em 1961. Fui eu quem os acolheu, por conta do Itamaraty. Nessa época, eu já havia sido nomeado Leitor de Estudos Brasileiros lá na África, no caso da Nigéria, e, depois, em Gana. Cabia a mim escolher os alunos que preencheriam as vinte vagas oferecidas pelo Itamaraty.

Fernando Rodrigues - Foi nessa época que o senhor lançou o livro Família de Santo, não?

Vivaldo da Costa Lima - Nessa época, em uma das minhas iniciações em método, eu fiquei como espécie de adido do laboratório de Fonética, sem ter nenhuma formação lingüística, mas eu acompanhava o professor Nelson Rossi em pesquisas no interior, que resultaram no famoso e clássico trabalho Atlas dos Falares Baianos, sobre a linguagem popular na Bahia. Isso tudo é minha experiência de formação, de pós-graduação. Foi lá, no laboratório de Fonética - que hoje, curiosamente, está na promotoria do Estado, no 
bairro de Nazaré -, naquela Faculdade de Filosofia, que eu conheci o professor Agostinho da Silva, de 1959 para 1960. Nessa época, inclusive, ocorreu o IV Colóquio Internacional de Estudos LusoBrasileiros, com apoio da Unesco. Foi um Congresso de muita repercussão, porque foi um congresso político. Pois, naquele tempo, Salazar ainda era o presidente de Portugal, houve então uma pressão muito grande dos portugueses sobre a cultura brasileira e, aqui, a esquerda brasileira estava naturalmente mobilizada contra esses movimentos colonialistas, tudo isso. Voltando ao meu livro. Esse trabalhozinho $^{10}$ é um trabalho histórico. Eu o escrevi justamente para a visita dos membros desse colóquio ao terreiro de Candomblé Ilê Opô Afonjá, naquela época sob a liderança da ialorixá Mãe Senhora. ${ }^{11}$ Foi então uma festa que Senhora ofereceu, a pedido da organização do colóquio, para esses portugueses, como também aos franceses e americanos. Eu, aí, descrevo a festa. É uma espécie de roteiro para a festa de Xangô no Opô Afonjá. Esse roteiro é a minha primeira obra publicada sobre candomblé. Mas voltando, ao que relatava antes, em 1960, eu conheci Agostinho da Silva. E ele me chamou assim, de repente, no fim do mesmo ano, para ir para a África, para ser uma espécie de leitor de estudos brasileiros, este era o posto que o Itamaraty dava aos professores que iam para lá, onde eu fiquei por três anos, entre Nigéria, Gana e o Daomé. Nessas regiões da África Ocidental estavam os pontos principais da minha reflexão, da minha pesquisa, focando as relações entre a cultura brasileira e a cultura africana. Bem, veio Jânio Quadros, veio a mudança de Jânio, veio a mudança da política internacional. Com tudo isso, eu voltei para o Brasil, naturalmente. E voltei a ensinar: passei a ensinar na Faculdade de Filosofia da Universidade da Bahia, como disse antes, no lugar do professor Thales de Azevedo, que tinha sido nomeado Diretor da Faculdade.

Edson Farias - Até então, como o senhor se sustentava?

Vivaldo da Costa Lima - Trabalhava no CEAO. Eu era pesquisador do CEAO, isso era remunerado, eu ganhava para isso. 
Edson Farias - Qual foi o tipo de pesquisa que o senhor desenvolveu durante a sua forma de pós-graduação?

Vivaldo da Costa Lima-Minha pesquisa foi toda direcionada para a cultura afro-brasileira. No caso, a pesquisa que resultou nesse livro é um levantamento das casas-de-santo da Bahia.

Fernando Rodrigues - Mas como surgiu o interesse pelo Candomblé?

Vivaldo da Costa Lima - Eu me decidi por uma visão crítica. Eu achava que os estudos até então, com algumas exceções, dos pioneiros clássicos, como Nina Rodrigues e Edison Carneiro e outros, e o próprio (Roger) Bastide, eram assistemáticos, eram episódicos. Ou seja, observavam fatores de uma visão muito etnográfica, muito descritiva, e eu estava já influído, por ser um "cristão novo" na Antropologia e como todo cristão novo, como todo comunista novo naquele tempo, como todo participante de um credo novo, ele é mais realista do que o rei, então eu passei a ser. Para suprir as minhas deficiências de formação acadêmica, antropológica no caso, eu passei a estudar Antropologia de maneira sistemática, daí é que vem essa biblioteca que eu tenho, que até hoje eu compro livros sobre Antropologia, porque eu queria suprir as minhas falhas de formação acadêmica. Por aí veio também o convite para ensinar, então eu tive mais obrigação ainda de estudar para ensinar. Então, passei a estudar o Candomblé de uma maneira científica, se você não acha muito pretensiosa esta expressão, de maneira sistemática. Fiz o primeiro levantamento das casas de terreiro de Candomblé na Bahia, nessa época. Aliás, eu explico isso nesse no livro. ${ }^{12}$ No primeiro capítulo, eu descrevo como criei uma espécie de equipe, incluindo o professor Júlio Braga, ${ }^{13}$ que estudava Filosofia, enfim, foi trabalhar comigo, e muitos outros que estão aí hoje sendo professores ou pais-desanto, que vem a ser a mesma coisa. Todos se desenvolveram muito nisso. Hoje são pessoas de referências absolutas nessa pesquisas. Eu tive o privilégio de orientar essa turma naquele tempo. Daí por 
diante, eu passei a ensinar as disciplinas antropológicas que me cambiam desde o momento em que substitui o professor Thales de Azevedo. Disciplinas como Antropologia Física - inclusive, como falei antes, naquele tempo a Odontologia era ligada à Medicina, a Escola se chamava Escola de Odontologia “anexa” à Faculdade de Medicina - então, eu não tive dificuldades em preparar um curso de Antropologia Física. Mas eu estava mais interessado mesmo na Antropologia Social, ou seja, no problema dos costumes, da cultura, e daí que veio essa minha orientação para estudar sistematicamente, sociologicamente ou socioantropologicamente, o Candomblé. E essa série de pesquisas redundaram não só nesse trabalho sobre a família de santo, mas tiveram influência em dezenas de outros trabalhos de professores de fora que vinham estagiar no CEAO. Isto tudo está levantado aí, uma parte da bibliografia. Sem cabotinismo, eu posso dizer que a primeira edição desse meu trabalho está citado em mais de oitenta e três obras sobre cultura brasileira e cultura, sobretudo, afro-brasileira. Qualquer livro daquele instante que você pegue e que trate de candomblé da Bahia, há que se encontrar uma referência a esse estudo, porque ficou como uma espécie de clássico. Que vocês me permitam o cabotinismo, digo clássico naquele sentido dado por Ítalo Calvino ao descrever os livros clássicos, como aqueles que ninguém lê e todo mundo cita.

Fernando Rodrigues - E depois do livro, como se deu o prosseguimento das suas atividades de pesquisador?

Vivaldo da Costa Lima - Quando eu encerrei essa pesquisa no CEAO, quando veio a reforma universitária (de 1968), o CEAO, que era um órgão autônomo, passou a ser um órgão auxiliar, um órgão dependente da Faculdade de Filosofia, e eu fui indicado formalmente para a Faculdade de Filosofia, já ensinando Antropologia e comecei a criar disciplinas antropológicas. Eu introduzi disciplinas novas no curso, a exemplo de Antropologia Política. Também outras como Antropologia Religiosa, Antropologia da Morte. Essa, da 
morte, foi criada especialmente para a Faculdade de Medicina, para os estudos e pesquisas de Ciências Médicas, Ciências da Saúde. Concomitantemente, eu continuava minhas pesquisas sobre Candomblé voltadas para o lado mais simbólico, quer dizer, da Antropologia Simbólica. ${ }^{14}$ Cada vez mais me interessei pelo problema do sacrifício. Tal foi o instante em que ocorreu a minha guinada metodológica para o estudo da comida baiana, a partir da comida religiosa, da comida sacrificial, da comida de santo, da comida de Candomblé, é sobre isso que eu estou escrevendo esse trabalho. O trabalho trata da comida de santo numa casa de Ketu da Bahia, é um estudo sobre a comida de Olga de Alaketu. ${ }^{15}$ Eu digo aqui, por exemplo, na introdução: "O tema da comida sacrificial dos Candomblés tem sido abordado de uma maneira quase que puramente classificatória nos chamados estudos afro-brasileiros. Ali encontramos listas de animais e comidas próprias de cada divindade, ou então receitas da culinária ritual, dadas com descrições breves, sobretudo quando fornecidas por pais ou mães-de-santo, etc.” Eu fiz um levantamento a partir da obra que eu acho que é de Manoel Querino, A Culinária na Bahia.

Edson Farias - Em termos de método, a proposta desta Antropologia da Alimentação obedece a um princípio quase fenomenológico, não?

Vivaldo da Costa Lima - Ah, sim. Eu queria, então, dar uma interpretação mais fenomenológica, mais antropológica ao problema da comida, compreendeu? E eu separei aqui até para vocês, não sei se eu vou achar aqui agora. Eu cheguei a criar esse Programa de Estudos da Alimentação na Faculdade de Filosofia há alguns anos, já aposentado. Cheguei a montar uma biblioteca para formar esse centro, mas não tive, naturalmente, o apoio que esperava ter da Universidade. Não estava ganhando nada, porque já estava aposentado, apesar disso a Universidade não me deu nenhum apoio formal de estagiário, de pesquisadores para me ajudar, e eu 
fui esperando, esperando e não houve nada disso, então eu resolvi terminar com esse projeto e deixei lá só a instalação, que era deles.

Edson Farias - Como se deu sua entrada no CEAO?

Vivaldo da Costa Lima - O CEAO é que entrou comigo. Eu fui o primeiro pesquisador do CEAO. Mas eu contei para vocês que o professor Agostinho da Silva, que teve a idéia da criação do CEAO, estava procurando pessoas, meio ...assim ..."marginais” na Universidade e suficientemente loucas para aceitarem um convite, o qual feito em uma praia em Itapuã, onde ele estava morando. Eu fui passar um dia com ele e ele convidou-me dia 15 de dezembro para uma viagem no fim do mês, depois do Natal. Naquele tempo, era uma coisa espantosa ir para a África. Naquele tempo não é como hoje, não tinha telefone, essa linhas diretas de avião, não é? Você tinha que viajar para Dakar e daí para a localidade que nos interessava pesquisar. O Agostinho conta isso de uma maneira curiosa num dos livros dele. ${ }^{16}$ Eu fui o primeiro louco, eu fui o primeiro funcionário contratado por Agostinho da Silva. Depois, veio o Valdir Oliveira.

Edson Farias - Mas vocês formavam uma roda de amigos, ou mesmo de pessoas interessadas no tema da cultura africana, círculo que já se reunia antes deste contato com o Agostinho da Silva?

Vivaldo da Costa Lima - Não, as coisas eram muito individualistas aqui. Pelo contrário, eu era considerado um cara que abandonou a profissão, que deixou de ganhar dinheiro como dentista para fazer essa loucura de voltar, já com quase trinta anos de idade, a estudar, para ensinar, ou seja, trocar uma carreira segura por outra tão sacrificada como é a carreira de professor. Por outro lado, eu achava a Universidade uma coisa fabulosa, porque me deu segurança nessa coisa intermediária de eu ter abandonado, "queimado", como eu costumava dizer, a Odontologia. Mas, voltando... Agostinho me encontrou no gabinete de Nelson Rossi, que já era da Universidade - onde eu já colaborava com Nelson, de uma maneira amadorística, 
sem nenhum vínculo com a Universidade, porque gostava das coisas. Esse grupo do qual você fala era o grupo de Nelson Rossi, que influenciou muito essa história. Eu só fui contratado pela Universidade em 1960, quando fui para África. Nessa época o reitor Edgar Santos me contratou para ajudar Agostinho a fundar o CEAO, eu fui um dos fundadores do CEAO. E lá eu tinha que ter um título, e deram um título: Agostinho me deu o título de Diretor Chefe das Pesquisas Etnológicas e Sociológicas. Daí então, elaboramos o Esquema básico para questionário da pesquisa nas associações religiosas do culto afro-brasileiro, juntamente com a relação dos 23 terreiros de Candomblé onde foi feita a primeira série de entrevistas, desses terreiros todos, só tem uma mãe-de-santo que é viva hoje, que é Olga do Alaketu. E ela é minha amiga até hoje.

Edson Farias - De maneira mais específica, qual era a natureza da atividade que realizava no CEAO?

Vivaldo da Costa Lima - Até então eu trabalhava somente no campo da pesquisa no Setor de Estudos Antropológicos e Sociológicos do Centro de Estudos Afro-Orientais, e eu era o setor, o setor era eu. Neste setor do CEAO, me coubera a orientação dos projetos de pesquisa no estudo da contribuição das culturas africanas ao processo civilizatório brasileiro. Embora naquele tempo me interessasse igualmente pelos problemas de relações raciais dentro de uma abordagem mais sociológica do que histórica, a pesquisa por mim dirigida no CEAO se orientava para uma revisão sistemática de um ponto de vista etnográfico e etno-histórico ${ }^{17}$ dos estudos que poderiam ser reunidos sob a epígrafe tradicional de afrobrasileiros, notadamente nas obras consideráveis e já clássicas de Nina Rodrigues, Manoel Querino, Arthur Ramos, Edison Carneiro e Luís Viana - este com o livro dele O Negro na Bahia, um dos grandes clássicos dos estudos africanos no Brasil. À medida que eu fui adquirindo um conhecimento por informação, pela vivência, pela 
pesquisa, por aquilo que muitos anos depois um antropólogo norteamericano, chamado Clifford Geertz, denominou de "descrição densa", isto é, não apenas a descrição superficial ou dos fatos evidentes de uma etnografia de campo, mas a parte, a vivência, a participação, aquilo que alguns antropólogos americanos chamam de observação participante, que não é exatamente isto, porque eu não participava para observar, eu observava participando, e há uma certa diferença metodológica nisso. Eu não fui para o Candomblé para estudar Candomblé, eu já ia ao Candomblé antes. Porque eu ia ao Candomblé, é que eu pude fazer essas pesquisas e, mais tarde, sistematizar essas pesquisas.

Edson Farias - Professor, havia alguma motivação política na sua ida ao Candomblé, a princípio?

Vivaldo da Costa Lima - Não, não creio que houvesse. Devia ter havido apenas uma coisa existencial. Há um ano, o jornalista do A Tarde me fez essa pergunta. Na matéria publicada eu respondo que não fui eu que descobri o Candomblé, foi o Candomblé que me descobriu; foi através do Candomblé que eu voltei a ter interesses, comecei a ter interesses sistemáticos pela religiosidade e essas coisas. Enfim, o Candomblé é que me descobriu mais do que eu a ele. Porque eu não fui estudar o Candomblé para escrever sobre o Candomblé. Quando eu fui para a Universidade, eu já era um freqüentador antigo do Candomblé, e porque eu era um frequentador do Candomblé é que eu pude organizar essas pesquisas com uma certa facilidade, um certo trânsito. Eu era amigo de todas as grandes casas da Bahia, não é?

Fernando Rodrigues - Na articulação com o professor Agostinho da Silva, como é que o CEAO se sustentava, pois a princípio não fazia parte da estrutura da Universidade?

Vivaldo da Costa Lima - Mas era um órgão autônomo. Isso está escrito inclusive em muitos lugares. Agostinho propôs a Edgar 
Santos a criação de um centro de estudos africanos. Edgar então propôs, para abrir mais o leque, inserir asiáticos também. Só com a reforma no tempo do filho do Edgar Santos - diga-se de passagem, uma mal fadada reforma -, foi que teve que integrar o CEAO a um órgão institucionalizado, no caso a Faculdade de Filosofia. Integração essa que, aliás, prejudicou muito o CEAO, porque diminuiu o seu ritmo, à medida que ficou mais burocratizado, porque passou a depender de um outro órgão acima dele, quando antigamente, no tempo de Agostinho, o CEAO dependia diretamente do reitor, fosse quem fosse o reitor. Enfim, na reforma, esses órgãos autônomos todos, não só o CEAO, mas o Instituto de Música, a Escola de Teatro, que eram órgãos autônomos, foram integrados ao corpus da Universidade, não sei com que vantagem.

Edson Farias - À exceção do reitor Edgar Santos, como era a recepção ao trabalho de vocês dentro da Universidade?

Vivaldo da Costa Lima - No começo, inclusive, havia uma certa hostilidade racista dentro da Universidade. Eu digo racista - porque eles próprios não admitem isso -, mas, na verdade, era racismo. A elite intelectual da Universidade, os velhos catedráticos, professores, não compreendiam a importância que aqueles estudos estavam tomando. Tanto que o próprio reitor que substituiu Edgar, o Farias, como é o nome dele? Rogério Farias, não é? Se ele não pôde acabar com o CEAO, ele tirou o apoio às pesquisas; ele não compreendeu a grandeza do trabalho e nem o alcance político do trabalho, coisa que o próprio Jânio Quadros, na sua loucura, entendeu muito bem. A propósito, não é demais lembrar que quando eu estava na África, Valdir Oliveira substituiu Agostinho, porque Agostinho foi criar outras coisas, ele criava as coisas e mudava de rumo. Agostinho em 1964, 1965 foi pra Brasília criar o Centro de Estudos Portugueses, lá na Universidade de Brasília.

Edson Farias - Como se deu sua aproximação com Antônio Carlos Magalhães? 
Vivaldo da Costa Lima - Horácio dizia: “A quem os deuses querem perder, primeiro enlouquecem”. Isso se aplica muito bem ao meu amigo Antônio Carlos - antes de ele ter enlouquecido, dos sonhos de grandeza e de hegemonia política, que o têm levado a tanta besteira, a tanta bobagem - ainda na época em que ele era um jovem prefeito de Salvador (1966-1970) interessado em criar algo de novo na administração pública, nessa época, ele teve a idéia de criar um projeto de renovação do centro histórico, não é? Eu fui convidado pelo Diretor do Departamento de Turismo da prefeitura, o jornalista Flávio Costa, para coordenar uma pesquisa sobre o Centro Histórico do Pelourinho. Eu estava na Universidade, então aceitei. Foi aí que eu conheci - conheci não, pois eu já conhecia Antônio Carlos da nossa infância comum ali, no Campo da Pólvora, onde fomos vizinhos - mas a proximidade se deu a partir desse levantamento que eu fiz, inclusive, com a ajuda de Júlio Braga, que foi meu assessor de pesquisa. Depois - quando Antônio Carlos resolveu institucionalizar o projeto -, naturalmente, eu fui convidado para ser secretário executivo do Projeto, com o diretor que era um arquiteto famoso do Rio de Janeiro, Vladimir Alves de Souza, como diretor executivo, que vinha aqui todo mês. Quando Antônio Carlos assumiu o governo do Estado, ainda sob a ditadura, eu fui convidado para ser diretor executivo, porque o Vladimir não podia mais estar vindo aqui e o trabalho tomou uma dimensão que precisava de um diretor presente, era para ser a primeira etapa do Largo do Pelourinho. Depois, já com a criação do Instituto do Patrimônio Artístico e Cultural da Bahia, eu fui diretor por três períodos, tanto no governo Antônio Carlos (1975-1979), quanto em uma parte do governo Roberto Santos, mas no Roberto Santos eu pedi demissão, não quis ficar porque era outro ambiente, e agora por último (1991-1995), quando o Antônio Carlos saiu do governo dele, eu também pedi para sair, não aceitei o convite de Paulo Souto (1996-2000). Já estava cansado, e já havia muita interferência política no órgão. Eu tinha outra idéia, uma idéia mais idealizada do projeto do Pelourinho. Importa dizer que não foi uma 
indicação política, foi uma indicação técnica. Eu fui o pesquisador chefe, eu fui quem fez o levantamento.

Edson Farias - Qual era o seu interesse pelo tema do Pelourinho naquela época?

Vivaldo da Costa Lima - O Pelourinho para mim era apenas uma parte histórica da cidade. Eu não tinha interesse teórico-metodológico, tinha interesse por gente, porque eu sou um antropólogo de gente, não sou antropólogo de Arqueologia. Sempre me interessei muito pelo Pelourinho - a prostituição, a droga, os veados, tudo aquilo que havia institucionalizado a vadiagem da área, isso sempre me interessou muito. ${ }^{18} \mathrm{O}$ projeto de reforma foi se desenvolvendo de uma maneira utópica. A proposta era que se conservasse a população tanto quanto possível. Ou seja, que se restaurasse para o povo, naturalmente; não para a marginália, para os marginais, nem para aquilo que o Agostinho da Silva chamava os despojados, os necessitados. Mas aí veio a loucura política, de apoio político, e começaram a distribuir os espaços por pessoas incompetentes para ocupá-los, aí o mundo de lojinhas, de restaurantezinhos sem uma certa formação profissional adequada. E a música? A música axé! Tudo aquilo causou aquela invasão, tudo isso... fizeram do Pelourinho então um bairro turístico, que não era essa a nossa intenção inicial. Queríamos um bairro em que houvesse vida, vida do povo, não é? Inclusive música, inclusive shows, e não mais como uma só predominância

Fernando Rodrigues - Como se deu inicialmente a restauração do Pelourinho?

Vivaldo da Costa Lima - Foram várias etapas. Começou com um levantamento socioeconômico daquela área do Pelourinho, e eu - como era amigo do Flávio Costa, que era diretor da Bahiatursa naquele tempo, e ele era ligado ao Antônio Carlos, que era, naquela época, prefeito-, eu fui convidado para assessorar como antropólogo, 
como sociólogo, para realizar aquela pesquisa. Aquela pesquisa foi um levantamento socioeconômico da área, ${ }^{19}$ observando as condições de vida dos moradores, a situação social, as hierarquias de mando ali dentro. Atentando, também, para os problemas da prostituição, da pobreza na área, da decadência física dos prédios, da ausência dos proprietários que eram de pessoas da grande burguesia baiana e que tinham aqueles prédios lá, arruinados, mas não se preocupavam em conservá-los, porque aquilo não dava renda suficiente para justificar qualquer investimento. Tudo isso foi difícil, porque nessa hora que se tocou na economia, nessa hora, o capitalismo se preocupa, e você vê lá muita gente que nunca tinha ligado para aqueles prédios, que estavam arruinados, de repente se lembraram que eram donos, proprietários, e passaram a exigir, naturalmente, compensações políticas e econômicas para esse projeto. De toda maneira, nessa primeira parte, eu não entrei. Ainda não existia o IPAC, o Instituto do Patrimônio, que naquele tempo foi criado com o nome de Fundação do Patrimônio Histórico e Cultural da Bahia. Eu realizei aquele projeto e entreguei ao prefeito, que era Antônio Carlos Magalhães, e daí o governador Luís Viana Filho.... Nessa ocasião, nós fizemos esse levantamento, veio a idéia de se criar uma Fundação para cuidar da renovação daquela área, da reconstrução, da renovação social e física do Pelourinho. Criou-se então a Fundação do Patrimônio Artístico e Cultural da Bahia, e eu fui convidado para ser o secretário executivo, já nessa época, acho que foi em 1969. O presidente era o grande arquiteto brasileiro Vladimir Alves de Souza, que morava no Rio de Janeiro, e que vinha sempre à Bahia, porque tinha interesses aqui. Ele foi o arquiteto da reitoria, da Universidade, foi o arquiteto restaurador do Museu de Arte Sacra. Tinha relações muito profundas com a cultura da Bahia devido à sua intervenção nos projetos da Universidade no tempo do reitor Edgar Santos, quando a Universidade realmente se preocupava com a cultura da Bahia, não só com a cultura acadêmica, como também com a cultura geral, com a cultura popular. Ele [o Edgar Santos] criou a Escola de Teatro, os seminários de música, o Museu de Arte Sacra, o Centro de 
Estudos Afro-Orientais e tanta coisa mais, profundamente enraizado na cultura baiana, nos valores baianos, isso do ponto de vista de Edgar Santos. Eu ficava na direção executiva do órgão. Começamos então os projetos do Pelourinho, começamos cautelosamente com Luís Viana a restauração do pequeno largo do Pelourinho, largo que dá nome à área, e ficamos ali. Alguns projetos particulares tiveram o apoio da gente, como o Senac. Saiu Luís Viana e entrou Antônio Carlos Magalhães, que continuou a desenvolver o projeto em um ritmo mais intenso. Antônio Carlos queria marcar sua passagem, naturalmente. Vocês conhecem tão bem quanto eu o temperamento político e a ambição dos projetos políticos do governador Antônio Carlos, sabem que ele realmente investiu muito ali no Pelourinho, já saindo do Pelourinho para as ruas mais degradadas da área, ou seja, o Maciel, as Laranjeiras, etc. Então, a Fundação foi transformada num Instituto do Patrimônio, como um órgão mais autônomo, ligado ao governo, e eu fui promovido, se isso se pode dizer assim, a diretor executivo do órgão. Foi aí que eu passei três períodos, os três períodos do governo de Antônio Carlos. Fui eu o diretor executivo desse Instituto que formou arquitetos especialistas em restauração, restauradores, pintores. Eu, sem ser arquiteto, era, entretanto, uma pessoa muito interessada no projeto sociológico, social de restauração humana, de recuperação humana, e uma coisa traz a outra: a recuperação da população estava incluída, ligada intimamente à recuperação física dos prédios. Foi um trabalho cheio de tentativas, que não havia tradição sobre isso, nunca se fez nada disso no Brasil, era uma coisa nova. Eu viajei um pouco para ver o que se tinha feito fora, o que se fez, por exemplo, nos Estados Unidos, um pouco em Filadélfia, mas já com outras bases econômicas, o que se fez em Paris e outros projetos desse tipo, ambiciosos, e que foram naturalmente modificados de acordo com as exigências econômicas de cada país. Nós aqui começamos a limpar a área, como se diz, fisicamente. As ruínas foram todas consolidadas. E começamos a ver o problema da prostituição, o problema da marginalidade ali dentro. Isso não 
foi feito sem protestos dos marxistas românticos. Houve atritos com essa esquerda burra - não a esquerda ideológica, que eu também me considero um homem de esquerda -, mas a esquerda burra, a esquerda radical, a esquerda dos falsos comunas daqui, da Bahia, e dos jornalistas também safados, interesseiros e meio canalhas também, da oposição ao governo de Antônio Carlos. Quer dizer, na verdade, quando eles foram contra o Projeto do Pelourinho, eles eram contra o governador Antônio Carlos, eles sabiam muito bem, porque não são estúpidos, não são burros, são apenas irracionais. O Projeto era necessário, era preciso, e ninguém podia restaurar o Pelourinho conservando ali as putas, os maconheiros. Bom, mas nós tínhamos que retirar as pessoas dos casarões abandonados pelos proprietários e essa retirada gerou comentários dos falsos esquerdistas, ainda que indenizássemos pessoas que não tinham, a rigor, nenhum direito, porque moravam lá sem pagar nada, eram invasores na verdade. Mesmo assim, eu insisti para que houvesse uma verba para a indenização das pessoas, o que eles faziam com esse dinheiro não interessava: alguns compraram as suas casas na periferia, outros mudaram para perto, alugaram, outros traficaram com esse dinheiro, porque eles eram traficantes, outros jogaram, perderam-se... isso é outro problema. É outro problema, mas, de toda maneira, eu tive problemas sérios.

Edson Farias - Quais foram os critérios adotados para a locação de um imóvel no Centro Histórico de Salvador, no tempo em que o senhor estava na frente do IPAC?

Vivaldo da Costa Lima - Os critérios eram os que nós tínhamos estabelecido no IPAC: competência se fosse casa comercial, competência para estabelecer um projeto comercial, só isso, competência e capacidade financeira.

Edson Farias - Isso passava por edital ou alguma coisa assim? Havia, se publicava um edital para candidatos concorrerem à locação de imóveis ou não? 
Vivaldo da Costa Lima - Não, não havia isso, não havia edital nenhum, porque nós tínhamos autonomia legal de escolher.

Edson Farias - O senhor não foi identificado como de “direita”, pela proximidade com o Antônio Carlos Magalhães?

Vivaldo da Costa Lima - Sim, eu fui. Mas eu vou lhe dizer que naquela época, na Universidade, quando procuraram um professor para fazer isso, encontraram a mim porque eu já trabalhava nessas pesquisas de campo, nessas coisas de Candomblé, eu já tinha contato com o povo, coisa que não era tradição dos professores da Universidade. Compreendem? Se me procuraram, com toda isenção eu lhe digo, foi por isso, não foi pelos meus belos olhos, que eu não os tinha, não é? Eu já tinha feito pesquisa sobre “aparadeiras”. O reitor precisou de pesquisa sobre aquelas parteiras populares, chamadas “aparadeiras”, que a Escola de Nutrição queria fazer um levantamento, não para expurgá-las, mas pelo contrário, para reciclá-las, como se diria hoje. Fui eu quem fez essa pesquisa, e tudo isso é do conhecimento público. Então quando o poder público precisou de alguém para coordenar essa pesquisa, me chamaram por isso, essa minha formação aberta, essa minha disponibilidade, de ser um homem que já naquele tempo ajudava nas pesquisas de (Pierre) Verger, enfim, pela minha disponibilidade. Talvez, também, pela minha, talvez, independência financeira, que eu não tinha família, não estava atrás de cargos, sabe como é? Tudo para mim estava ótimo. E tudo isso concorreu, a minha liberdade, a minha independência política, a minha ideologia - sou sabidamente um homem de esquerda, mas não radical, não um comunistazinho analfabeto. Tudo isso concorreu para que eu fosse levado a isso. E lá, então, eu descobri um mundo que eu não conhecia direito: a miséria, a fome, a prostituição. Daí passei a descobrir coisas, passei a estudar, passei a viajar, passei a ler ... Muita gente de fora, que ia me visitar, pensava que eu era arquiteto - eu nunca fui arquiteto -, porque eu falava como arquiteto, usando uma linguagem do 
arquiteto, porque tinha dezenas de arquitetos trabalhando comigo, alguns bastante inteligentes, com quem eu aprendi muita coisa.

Fernando Rodrigues - Como o senhor descreveria essa ideologia que o senhor levou, vamos dizer assim, entre aspas?

Vivaldo da Costa Lima - Eu era um liberal de esquerda, pode-se dizer assim, eu era um liberal de esquerda, um homem, um democrata de esquerda. Embora haja contradição nisso, democracia não tem nada a ver com esquerdismo, não há democracia, nunca houve democracia no País. Mas eu era um cara preocupado com a promoção das classes subdesenvolvidas, das classes miseráveis, das classes pobres, da integração racial, da reparação das injustiças raciais no Brasil, do domínio do capitalismo branco sobre uma maioria de negros dependentes. Também nunca fui um demagogo para fazer do negro uma vítima sem ação, pois a dependência do negro vai muito da incapacidade que ele teve, não é incapacidade física nem mental, mas a incapacidade política de lidar com o sucesso para a sua afirmação, coisa que só recentemente começou a ocorrer, no início do século passado, com as ligas operárias, as associações de classe, os sindicatos. Porque a escravidão marcou muito o negro, não é? A escravidão foi até 1888, durante cinqüenta anos o negro ainda ficou tateando. A partir dos anos trinta do século XX é que o negro começou realmente a existir de maneira um tanto mais autônoma. Quando você via um professor negro era uma exceção, era uma coisa assim para ser mostrada como uma novidade, mas o negro no Brasil sempre foi um lutador. Veja aqui na Bahia, por exemplo, a justiça baiana, o Tribunal de Justiça. Todos os funcionários burocratas, todos, mais de 90\%, funcionários burocratas, escrivões de ofícios, escrivões de varas públicas, eram negros. Havia uma tradição, essa mãe-de-santo, Estela (do Ilê Opô Afonjá), era neta de um chefe dos escrivões da Justiça. Quer dizer que o negro não era só um marginal; ao lado da marginalidade havia uma classe já ascendente. O professor Thales de Azevedo escreveu um livro curioso, nos anos 
quarenta, sobre as elites de cor na sociedade baiana, ${ }^{20}$ naquele tempo “de cor”, porque ainda não se podia falar "negro", não é? Que é um livro que já mostra essas elites negras no processo brasileiro, e quer dizer que tudo isso já era uma atitude antirracista, estudar isso já era prova de ser antirracista, mostra que o negro não era aquela coisa dependente, inferior, como pensaram muitos, muitos afirmaram e alguns continuam pensando.

Edson Farias - E resgatar o Pelourinho também era uma atitude antirracista?

Vivaldo da Costa Lima - Ah, sim, o projeto do Pelourinho foi uma atitude antirracista, sem dúvida. Quem morava ali era negro e branco pobre, branco miserável que era um negro, socialmente um negro. Da mesma maneira que um negro doutor era socialmente branco. Vou contar uma história interessante: eu conheci um cidadão chamado rofessor Enoque Carteado, muito conhecido aqui na Bahia, essa família Carteado é composta de vários doutores. Ele uma vez vinha com o carro - no tempo que na Bahia os negros que tinham carro faziam questão de comprar carros bem marcantemente esportivos, para não se confundirem com os táxis, que naquele tempo não eram pintados, identificados, com pintura identificadora de táxi, eram carros comuns, com motorista, nos pontos de táxi. Então, ele passava pela Rua Chile e uma senhora acenou para ele, que parou o carro. Ela entrou no carro. Como chovia, ela foi logo dizendo: "Me leve em tal lugar na Vitória, em tal lugar, na casa de Dr. Fulano”. A coincidência é que o tal fulano, o marido dela, era colega do médico, o médico preto no carro, mas como ela viu um preto no carro... Isso aconteceu realmente, ele me contou, fez parte do folclore familiar. Era um negro muito elitizado, tanto que ele botou nos filhos apenas nomes gregos. Ela chegou em casa e disse: "Olha o senhor me desculpe, motorista, eu sou mulher de Dr. Fulano de tal, mas estou desprevenida aqui de dinheiro. O senhor venha depois, por favor, receber a corrida, porque eu não posso pagar o senhor agora que eu 
estou desprevenida”. Ele respondeu: “Pois não, não é problema”. E, de noite, ele voltou e quando a empregada chegou, ele deu o cartão dele, Dr. Nivaldo Carteado. Aí o professor, que estava na mesa, o colega dele de faculdade: "Oh, Nivaldo! Que novidade você por aqui. Por favor, entre, faça o favor, estou acabando de jantar, venha tomar um cafezinho, entre”. No que respondeu: “Não fulano, eu vim aqui a serviço, porque a sua mulher tomou o meu carro hoje e disse que eu viesse receber a corrida”. Um vexame. Na casa dele, todas as empregadas eram brancas. E naquele tempo uma família que se prezava, tinha quatro ou cinco empregadas, não tinha uma só, não se podia ter uma só.

Edson Farias - A respeito das suas pesquisas no CEAO, o senhor acha que o que vocês fizeram, o que vocês pesquisaram, o que vocês conceberam naquele momento, enfim, todo o conhecimento produzido sobre a cultura africana no Brasil teve repercussão em termos da maneira como se definiram estratégias de ação dos grupos subalternos, políticas públicas relacionadas com a área de cultura aqui na Bahia?

Vivaldo da Costa Lima - Eu acho que tem, porque não fomos nós apenas, foi o diretor, Agostinho da Silva que era um homem político, não é? E que, naquele tempo, Jânio Quadros, ele realmente criou no Itamaraty, a Divisão da África. Naquele tempo, a África era um exílio, havia poucas embaixadas. Nós é que criamos tudo isso, Agostinho da Silva foi quem criou tudo isso. Eu acho que o CEAO teve uma importância muito grande nesse plano de relações nacionais e internacionais com a África, mandando para lá professores, leitores de estudos brasileiros, leitores de português, como a professora Ieda de Castro com o marido, o professor Pedro Moacir Maia, que foi para o Senegal, eu que fui para Nigéria, a professora Ieda que foi para o Congo, professores que mostraram a importância do intercâmbio, trazendo estudantes bolsistas para cá, compreendeu? Tudo isso está na correspondência com a reitoria e 
com o professor Agostinho da Silva. Estão publicando em Portugal toda a literatura dele, não só literatura como também a parte política da obra dele, ${ }^{21}$ onde trata disso. Ao mesmo tempo, o CEAO foi decisivo para legitimar os modos de ser e viver de toda essa gente negra e pobre, mostrou a importância de convidar essa gente de santo e tal, de fazer cursos de línguas africanas.

\section{Notas}

1. Sobre o desenho dessa aliança entre ciências sociais e nação, mas pelo viés da discussão em torno do popular no Brasil, consultar Peirano (1992). Para uma reflexão contemporânea a respeito dos rumos tomados pelo mesmo dueto, ver Velho (2008).

2. A respeito do lugar ocupado pelos estudos envolvendo o debate sobre etnia, etnicidade e identidade étnica no Brasil, um documento importante por sintetizar aspectos aprofundados por autores como Roberto Cardoso de Oliveira é Etnias e Culturas no Brasil de Manuel Diégues Jr. (1972). No livro, o autor toma o contato cultural como demiurgo à compreensão de como se relacionaram, no Brasil, os temas do desenvolvimento socioeconômico e da diversidade cultural da população brasileira.

3. Edgar Santos se destacou entre os nomes que encabeçaram, na década de 1950, os projetos de modernização econômica e cultural da Bahia, em um momento no qual eram dados os primeiros esforços de industrialização do Estado. Médico, ele é eleito o primeiro reitor da Universidade da Bahia e administra-a entre 1946 e 1961. Ele, a princípio, orienta a nova instituição para formar quadros técnicos para o setor industrial. Mas a herança mais significativa de sua administração foi a execução do projeto estético-cultural, dentro do qual inaugurou o Museu de Arte Sacra, o Museu de Arte Popular e o Museu de Arte Moderna, todos assinados pela arquiteta italiana Lina Bo Bardi. Além de viabilizar a ida de artistas estrangeiros vinculados a vanguardas estéticas para compor o quadro docente das respectivas Faculdades de Dança, de Música e de Teatro. Ver Aragão (1999). 
4. A obra de Waldir Freitas Oliveira traduz tanto seu interesse pelos vínculos entre cultura africana e sociedade e cultura brasileiras (cf., especialmente, Oliveira, 1966, 1967, 1969, 1975) quanto enfoca o processo mesmo dos estudos africanistas no país (Oliveira, 1976).

5. A obra completa será reeditada no primeiro semestre do próximo ano, pela editora Corrupio em quatro volumes.

6. Contando com apoio do Programa Pibic/UFBa-CNPq, a pesquisa $A$ invenção da Bahia como tradição na modernização baiana (2001-2004), fez parte do escopo do programa de pesquisa sobre "Ressignificações de domínios de memórias em contextos de modernização”, implementado entre os anos de 2001 e 2004, no grupo de pesquisa sobre Cultura, Memória e Desenvolvimento, o qual estava, na ocasião, vinculado ao programa de Pós-Graduação em Ciências Sociais da Universidade Federal da Bahia.

7. Instituição de ensino superior pioneira no ensino da medicina no País, essa faculdade também abrigou, entre o final do século XIX e início do século XX, um dos principais pólos para o desenvolvimento da ciência antropológica no Brasil. Movidos pela preocupação com a "higiene pública", alguns quadros médicos voltaram-se para o tema da "higiene mental”, tomando a população negra e pobre da capital baiana como espécie de "laboratório" para suas pesquisas e intervenções. O credo evolucionista compartilhado por vários desses intelectuais da virada do século remete o popular à "primitividade" ou "barbárie" da espécie humana, não vista mais no quadro específico de um povo, mas segundo o espelho do modelo elevado à condição de universal da humanidade racional-científica européia. Logo, tudo o que antecede à instauração do presente hegemônico passa a corresponder ao atraso. Eis o ponto: o Brasil, na versão da chamada geração de 1870 , consistiria em uma sociedade fadada ao atraso, afinal o passado encontrara aqui um berço esplêndido para sobreviver à higiene do progresso. Por certo já existe latente a referência ao conflito entre transformação e tradição, só que a última aparece envolta em teias de aranha, figurando a obscuridade e a superstição. Nina Rodrigues é certamente um notável exemplo. Médico maranhense, considerado pioneiro dos estudos antropológicos no Brasil desenvolveu o interesse pela religião das populações negras, 
principalmente as da Bahia. Com as lentes das teorias raciológicas, em Os Africanos no Brasil, ele conclui que o caráter “animista” dos cultos afro-brasileiros articulava-os à incapacidade mental dos africanos e seus descendentes de acompanhar a sistemática da vida civilizada. Ver Correa (1998) e Schwarcz (1993).

8. A Faculdade de Filosofia da Bahia, fundada em 1941, foi uma das primeiras instituições do gênero no Brasil. Ao longo desse período, além da graduação em Filosofia, abrigou cursos nas áreas de ciências humanas - como Letras, Geografia, Psicologia e Ciências Sociais.

9. Ver Castro (1976).

10. O antropólogo refere-se ao texto editado em 1959, Uma festa de Xangô no Opô Afonjá.

11. Mãe Senhora consolidou a tradição do Ilê Opô Afonjá, ao longo dos anos de 1940 e 1950. Tornou-se importante interlocutora de Pierre Verger em seus estudos sobre o Candomblé. Ela herdou o posto de babalorixá de Mãe Aninha (Eugênia Ana dos Santos), um dos nomes mais prestigiados da história das lideranças do Candomblé baiano nos anos de 1930. Ao lado de outro importante sacerdote, Eliseu Martiniano do Bomfim, Mãe Aninha encabeçou alianças fundamentais para a relativa tolerância por parte da policia com as atividades religiosas afrobrasileiras, naquele momento. Em 1937 tem destacada participação no II Congresso Afro-Brasileiro, realizado em Salvador, por organização de Édison Carneiro e Arthur Ramos. Consultar Lima (1987), Parés (2006).

12. A família de santo nos candomblés jejes-nagôs da Bahia: um estudo de relações intragrupais.

13. Representante da segunda geração do CEAO, posteriormente professor da Faculdade de Filosofia e Ciências Humanas da UFBa e, mais recentemente, presidente do IPAC, Júlio Braga é autor de textos angulando traços etno-históricos - ver Ancestralidade afro-brasileira: o culto de babá egum, de1992 -, mas também voltados às lutas históricas de afirmação do Candomblé na Bahia - ver Na gamela do feitiço, de 1995. 
14. Entre outras referências, ver Lima (1966).

15. O entrevistado faz referência ao artigo "Comida de Santo numa Casa de Kêto na Bahia”.

16. Ver Silva (2002b).

17. A respeito, ver Lima (1976, 1982, 1999).

18. Ver Lima (1989).

19. Consultar Pelourinho ... (1967).

20. A referência é ao livro As elites de cor numa cidade brasileira. (Azevedo, 1996).

21. A referência é a Agostinho da Silva (2002a).

\section{Referências}

AGOSTINHO, Pedro. Agostinho da Silva: pressupostos, concepção e ação de uma política externa do Brasil com relação à África. Afro-Ásia, CEAO/UFBa, n. 16, p. 9-23, 1995.

ARAGÃO, Rita de Cássia. O contexto de gestação da Universidade da Bahia. In: . A ousadia da criação: universidade e cultura. Salvador: Universidade Federal da Bahia, Faculdade de Comunicação, 1999. p. 35-63.

AZEVEDO, Thales de. As elites de cor numa cidade brasileira: um estudo de ascensão social \& classes sociais e grupos de prestígio. Salvador: EDUFBa, EGBA, 1996.

BASTIDE, Roger. O Candomblé da Bahia. 2. ed. São Paulo: Cia das Letras, 2001.

CARNEIRO, Edison. Candomblés da Bahia. 6. ed. Rio de Janeiro: Civilização Brasileira, [1984] 1978. . Religiões negras: negros bantos. 2. ed. Rio de Janeiro: Civilização Brasileira; Brasília: INL, [1963] 1981. 
CARVALHO, Maria Alice Rezende. Temas sobre a organização dos intelectuais no Brasil. RBCS, São Paulo, v. 22, n. 65, p. 20-27, out. 2007.

CASTRO, Ieda Pessoa. Antropologia e lingüística nos estudos afrobrasileiros. Afro-Ásia, CEAO/UFBa, p. 211-226, 1976.

CORREA, Mariza. As visões da liberdade. Bragança Paulista (SP): EDUSF, 1998.

DIÉGUES JR., Manuel. Etnias e culturas no Brasil. Rio de Janeiro: Paralelo, 1972.

GUIMARÃES, Antônio Sérgio. Comentários à correspondência entre Melville Herskovits e Arthur Ramos (1935-1941). In: PEIXOTO, Fernanda A.; PONTES, Heloísa; SCHWARCZ, Lilia M. (Orgs.). Antropologia, história, experiências. Belo Horizonte: Ed. UFMG, 2004.

O Projeto UNESCO na Bahia. In: PEREIRA, Cláudio Luiz; SANSONE, Livio (Orgs.). Projeto UNESCO no Brasil. Salvador: EDUFBA, 2007. p. 25-37.

HERSKOVITS, Melville. The negro in the New World: the statement of a problem. American Anthropologist, v. 30, n. 1, p.145-155, 1930.

LANDES, Ruth. A cidade das mulheres. 2. ed. Rio de Janeiro: EDUFRJ, 2002.

LIMA, Vivaldo da Costa. Uma festa de xangô no opô afonjá. In: COLÓQUIO INTERNACIONAL DE ESTUDOS LUSO-BRASILEIROS, 4. Salvador, 1959. Anais... Salvador: Universidade da Bahia, Unesco, 1959.

. Os obá de Xangô. Afro-Ásia, CEAO/UFBa, n. 2/3, p. 5-36, 1966.

. O conceito de nação nos candomblés da Bahia. Afro-Asia, CEAO/ UFBa, p. 65-90, 1976.

. Organização do grupo de candomblé: estratificação, senioridade e hierarquia In: MARCONDES DE MOURA, Carlos Eugênio (Org.). Bandeira de Alairá. São Paulo: Novel, 1982. 
LIMA, Vivaldo da Costa. O candomblé da Bahia na década de trinta. In: OLIVEIRA, Waldir Freitas; LIMA, Vivaldo da Costa. Cartas de Édison Carneiro a Arthur Ramos (De 04 de janeiro de 1936 a 06 de dezembro de 1938). São Paulo: Corrupio, 1987. p.39-73.

. Festa e religião no Centro Histórico. Afro-Ásia, CEAO/UFBa, p. 70-79, 1989.

. Liderança e sucessão, coerência e norma no grupo de candomblé. In: Moura. C. E. M. de (Org.): Leopardo dos Olhos de Fogo: escritos sobre a religião dos orixás. São Paulo: Ateliê Editorial, 1999.

LIMA, Vivaldo da Costa. A família de santo nos candomblés jejes-nagôs da Bahia: um estudo de relações intragrupais. Salvador: Corrupio, 2003.

MAIO, Marcos Chor. O Projeto Unesco e a agenda das Ciências Sociais no Brasil dos anos 40 e 50. RBCS, São Paulo, n. 41, out. 1999.

OLIVEIRA, Waldir Freitas. Brancos e negros em Angola. Afo-Ásia, CEAO/UFBA, n. 1, 1966.

. O Brasil e a nova África. Revista da Bahia, n. 7, 1967.

. Considerações sobre o preconceito racial no Brasil. Afro-Ásia, CEAO/UFBA, n. 8/9, 1969.

. Brasileiros negros e negros africanos. Cultura, MEC, Rio de Janeiro, v. 5, n. 17, 1975.

. Desenvolvimento dos estudos africanistas no Brasil. Cultura, MEC, Rio de Janeiro, n. 23, 1976.

. [Entrevista]: As pesquisas na Bahia sobre os afro-brasileiros. Revista Estudos Avançados, São Paulo, v. 18, n. 50, jan./abr. 2004.

OLIVEIRA, Waldir Freitas; LIMA, Vivaldo da Costa. Cartas de Édison Carneiro a Arthur Ramos (de 04 de janeiro de 1936 a 06 de dezembro de 1938). São Paulo: Corrupio, 1987.

PARÉS, Luis Nicolau. A formação do Candomblé: história e ritual da nação jeje na Bahia. Campinas (SP): Unicamp, 2006. 
PEIRANO, Mariza. A Legitimidade do Folclore In: SEMINÁRIO CULTURA POPULAR E FOLCLORE. As várias faces de um debate. Rio de Janeiro: IBAC, 1992.

PELOURINHO: levantamento sócio-econômico. Salvador: IPAC, Superintendência de Turismo da Cidade de Salvador, 1967.

PIERSON, Donald. Brancos e pretos na Bahia: estudo de contato racial. São Paulo: Cia Nacional, 1945.

PIERSON, Donald. As culturas negras no Novo Mundo. São Paulo: Ed. Nacional, 1979.

RAMOS, Arthur. A mestiçagem no Brasil. Maceió: UFAL, 2004.

RODRIGUES, Nina. Os africanos no Brasil. Brasília: UnB, 2004.

- O animismo fetichista dos negros baianos. Rio de Janeiro: EDUFRJ, 2006.

SCHWARCZ, Lilia. O espetáculo das raças. São Paulo: Cia das Letras, 1993.

SILVA, Agostinho da. Ensaios sobre Cultura e Literatura Portuguesa e Brasileira. Camarate: Círculo de Leitores, 2002a.

Da existência do CEAO. In: BORGES, Paulo A. E. (Org.). Ensaios sobre cultura e literatura portuguesa e brasileira, v. I. Camarate, Portugal: Círculo de Leitores, 2002b.

STOCKING JR., George (Ed.). American Anthropology (1921-1945): papers from the American anthropologist. Lincoln: University of Nebraska Press; 2002. Introduction.

VELHO, Gilberto. Antropologia e o Brasil, hoje. RBCS, São Paulo, v. 23, n. 66, p. 7-9, fev. 2008.

YELVINGTON, Kevin A. Melville J. Herkovits e a institucionalização dos estudos afro-americanos. In: PEREIRA, Cláudio Luiz; SANSONE, Lívio (Orgs.). Projeto Unesco no Brasil. Salvador: EDUFBA, 2007. p. $149-172$. 